\title{
Polyacrylamide Gel
}

National Cancer Institute

\section{Source}

National Cancer Institute. Polyacrylamide Gel. NCI Thesaurus. Code C45309.

An electrophoresis gel composed of polyacrylamide in an aqueous buffer. 